\title{
O PORTUGUÊS COMO CURSO UNIVERSITÁRIO NUM PAÍS DO NORTE: O CASO DA NORUEGA
}

\author{
PORTUGUESE AS A UNIVERSITY COURSE IN A NORDIC COUNTRY: \\ THE CASE OF NORWAY
}

\author{
Jan Engh*
}

\begin{abstract}
RESUMO
O português surgiu há 50 anos como curso na Universidade de Oslo (Noruega), por ser um canal importante de cultura, a fim de completar o ensino e a pesquisa romanísticos, e por razões práticas na esfera da indústria e dos negócios. De facto, a iniciativa partiu do último setor, embora preparada por um romanista. Com o tempo, o português tornou-se um curso como os outros. Contudo, com a mudança da ideologia da universidade e uma reorganização administrativa, os ideais académicos foram relegados a segundo plano. Também as considerações sociais e políticas foram negligenciadas. Cada vez menos recursos foram sendo atribuídos ao português, e a consequente baixa inevitável da procura por parte dos estudantes legitimou uma redução drástica do curso, testemunhando o desaparecimento do verdadeiro interesse pelos países e culturas lusófonos, não só da parte dos gestores académicos e da indústria, mas também do atual governo norueguês.

Palavras-chave: línguas estrangeiras; planeamento e liderança de universidades; língua portuguesa; Noruega.
\end{abstract}

\section{ABSTRACT}

Portuguese was adopted as a subject at the University of Oslo (Norway) more than 50 years ago as an important channel for culture, because of its place in Romance studies, as well as for practical reasons. In fact, the initiative came from the private sector, although the ground had been prepared by a Romance philologist for many years already. Over time, Portuguese became a subject just like any other. However, with the change of university ideology and the implementation of a new administrative model, academic ideals lost in importance and social and political considerations were neglected as well. Less resources were allocated to Portuguese, and an inevitable decline in the number of new students served as a justification for a drastic reduction of the subject, which, in turn, can only be seen as a lack of true interest in the Portuguese-speaking countries as far as the university's leadership and the managers of the private sector are concerned, but even the present Norwegian government.

Keywords: foreign languages; university planning and management; Portuguese language; Norway.

\section{INTRODUÇÃO}

\subsection{Cursos de línguas estrangeiras}

Iniciar o estudo de uma língua estrangeira não é geralmente considerado problemático, pelo menos não do lado "estrangeiro" - na comunidade onde se fala a língua. Lá, a própria língua é sempre o meio natural de comunicação. Também se tem orgulho na própria língua e na literatura e imagine-se que aprender essa língua só tem vantagens.

Do lado do acolhimento, no país onde a língua é uma língua estrangeira, o importante é a possibilidade de ter contacto com outra parte do mundo, e quando se identifica uma língua estrangeira como útil, os estudos da língua são iniciados e desenvolvidos com o andar do tempo. Isto é: em teoria. Na prática, exatamente em que língua estrangeira apostar é um ponto em aberto. Mais tarde, os custos de iniciar e continuar o ensino são calculados, e como o adotar no próprio sistema de educação examinado.

Ou seja, a visão de uma língua como língua materna e a visão dessa mesma língua como língua estrangeira são fundamentalmente diferentes. O ensino duma língua estrangeira não tem só a ver com convivência, geografia e distâncias, mas também com política. Para não mencionar o aparelho burocrático nem sempre consciente dos ideais da sociedade ou da política do próprio governo. Entretanto, a discussão na literatura especializada sobre o ensino das línguas concentra-se em geral nos aspectos técnicos: por um lado, assuntos práticos - arranjar professores, salas de aula, organizar exames e utilizar meios audiovisuais -, por outro lado, assuntos "internos" - temas da linguística contrastiva e o papel de (que tipo de) gramática, que métodos (imersão, etc.). Toma-se como dado adquirido que as condições político-administrativas, de natureza externa, já foram resolvidas de uma vez por todas, e que todos concordam que o ensino de língua estrangeira é desejável. Infelizmente, esse não é sempre o caso, mesmo quando

\footnotetext{
* Universidade de Oslo, Noruega. jan.engh@ub.uio.no

Orcid: https://orcid.org/0000-0002-4237-3062
} 
a iniciativa de iniciar o ensino da língua estrangeira vem do país em que a língua é estrangeira. $O$ caso do português na Noruega é um exemplo. A história do português como língua estrangeira não é só uma série de avanços e de progresso. Também conhece reveses, um deles sendo o caso do português na Noruega.

\subsection{A língua portuguesa e a Noruega}

Sendo uma das línguas mais faladas no mundo, ${ }^{1}$ o português tem uma importância cultural e económica significativa. Para um país como a Noruega, Portugal, Moçambique e Angola são importantes devido aos contatos culturais e comerciais, mas sobretudo o Brasil representa um parceiro comercial de peso, e a contribuição norueguesa para a economia brasileira também não é negligenciável. ${ }^{2}$ Paradoxalmente, o Brasil foi até 2019 o maior destinatário de apoio financeiro da Noruega - ligado à proteção do meio ambiente e especificamente da selva amazónica. Além disso, a indústria e o governo norueguês têm mostrado um interesse cada vez maior na cooperação em pesquisa e desenvolvimento, o que é testemunhado por um grande número de delegações de alto nível enviadas ao Brasil.

Já na década de 1950 se davam as primeiras cadeiras de português na maior e mais antiga universidade da Noruega, a Universidade de Oslo, a única universidade da Noruega com essa oferta, e em 1967 uma doação desencadeou o ensino regular. Depois de um início modesto, o português ficou apto a funcionar como um curso de língua estrangeira normal - de linguística, literatura e conhecimento da cultura e da sociedade. Infelizmente, o interesse oficial norueguês pela língua portuguesa e pela cultura lusófona diminuiu com os anos, em contraste com as declarações oficiais e apesar da importância de sustentar uma verdadeira comunicação entre os vários países.

Este artigo resume a história do ensino do português como curso universitário na Noruega.

\section{0 INÍCIO}

\subsection{Um pioneiro e o estabelecimento do curso}

Em 1949, o então estudante Leif Sletsjøe (1921-82) escreveu um artigo no jornal norueguês Verdens gang intitulado "Latin-Amerika og vi", 'A América Latina e nós', em que criticava a influência da tradição historiográfica anglo-americana sobre os historiadores nacionais e sobre a opinião norueguesa, em geral mal informada em tudo o que tinha a ver com a América do Sul (SLETSJØE, 1949). Sletsjøe sublinhava a importância de adquirir informação sobre este continente sem mediações - em especial destacava o Brasil como uma nação cada vez mais importante no mundo e salientando que para perceber o Brasil em primeira mão é preciso saber português. Nos anos seguintes, Sletsjøe escreveu vários outros artigos sobre o assunto e sobre a falta dum ensino académico da língua portuguesa na Noruega, sendo o mais importante o que ele escreveu em 1953 (SLETSJØE, 1953).

Sletsjøe apresentava argumentos duma natureza prática, baseados no que seria necessário para a indústria e para o comércio nacional, não se esquecendo da importância da cultura e da literatura lusófona, sobre qual já tinha começado a publicar artigos e a falar na rádio como filólogo, além de fazer traduções. ${ }^{3}$ Não via incoerência nenhuma entre a vida prática e a alta cultura. Para ele, a língua era fundamental.

Nos anos 1950, Sletsjøe deu aulas de língua portuguesa na Universidade de Oslo, embora não fosse possível formar-se em português na época. Passados alguns anos, Sletsjøe foi nomeado professor catedrático de francês no Norges handelshøyskole (Instituto superior de comércio) e mudou-se para Bergen, a segunda maior cidade da Noruega. Deixou de haver aulas de português em Oslo, até que, em 1967, houve notícias de uma doação da companhia de navegação Øivind Lorentzen A/S, do Rio de Janeiro, para financiar um leitorado na Universidade de Oslo durante cinco anos - na condição de que a universidade incluísse esse leitorado no seu orçamento depois dos cinco anos. Essa doação deveu-se, segundo o comunicado à imprensa relatado em todos os jornais noruegueses de alguma

1. 258 milhões de falantes segundo Ethnologue, https://www-ethnologue-com.ezproxy.uio.no/guides/ethnologue200. Acesso em 12 de março 2021.

2. Segundo o embaixador do Brasil na Noruega, George Monteiro Prata numa entrevista. Disponível em: http://www2.planalto.gov.br/ acompanhe-planalto/releases/2017/06/com-investimentos-de-us-2-bi-noruega-se-torna-8o-maior-parceiro-do-brasil. Acesso em 4 de outubro 2018

3. Por exemplo, o romance A Selva de José Maria Ferreira de Castro. (CASTRO 1953) 
importância: "A importância que a língua e a cultura portuguesa têm para Noruega, através das ligações portuguesas e brasileiras, é considerável." ${ }^{4}$.

\subsection{A universidade e os primeiros professores}

$\mathrm{Na}$ altura, a Universidade de Oslo encontrava-se num processo de grande expansão: a primeira geração pósguerra, correspondente a um aumento demográfico importante, tinha começado a estudar, e o corpo docente foi expandido em conformidade. Paralelamente, houve uma expansão qualitativa na Faculdade de Letras. Cada vez mais línguas estrangeiras foram adotadas como disciplinas universitárias. Assim, a Universidade de Oslo refletia bem o desenvolvimento geral da sociedade norueguesa na altura. Depois de duas décadas de reconstrução após a Segunda Guerra Mundial, incluindo cinco anos de ocupação alemã, a Noruega abriu-se culturalmente ao mundo, indo além dos países mais próximos.

Mesmo assim, tudo indica que a Universidade de Oslo foi apanhada desprevenida pela doação do leitorado. Foi preciso organizar o ensino desde o princípio, e dois estudantes avançados foram escolhidos para partilhar o leitorado temporariamente: Martin Indregard (1941-) e Francis Aubert (1947-), com o apoio e a orientação de Leif Sletsjø, que voltou a Oslo em 1970 como professor catedrático de filologia ibero-românica. As aulas começaram em janeiro de 1968.

Aubert provinha duma família norueguesa-brasileira, e Indregard já se tinha formado em português na Universidade de Estocolmo, na Suécia. Contudo, os dois tiveram companhia dentro em pouco: A fim de reforçar o corpo docente, a Faculdade de Letras pediu um leitor português ao Instituto de Alta Cultura em Portugal. A resposta foi positiva, e, em 1969, João Camilo dos Santos (1943-), formado pela Faculdade de Letras da Universidade de Lisboa, começou a trabalhar como leitor, ficando no cargo durante dois anos. Aubert voltara ao Brasil já em 1970, ${ }^{5}$ e Indregard saiu da universidade em 1973.

\subsection{Exames}

Só em 1970 foi possível fazer exames de português. Primeiro bacharelato, ["mellomfag"], e, a partir de 1971, mestrado ["hovedfag"]. Com a reforma dos estudos universitários institucionalizada de 2003, o bacharelato e o mestrado foram modificados para se enquadrarem na implementação norueguesa da reforma a seguir à Declaração de Bolonha. Em anexo, encontra-se um esboço da organização da Faculdade de Letras da Universidade de Oslo e uma descrição dos exames antes e depois da reforma de 2003.

\subsection{Objetivo do ensino}

Segundo o catálogo da Faculdade de Letras do ano letivo 1970/71, o objetivo do ensino do bacharelato de português era:

a) dar ao estudante uma introdução à língua portuguesa moderna para que perceba e a use por escrito e oralmente.

b) ajudar o estudante a adquirir uma compreensão das sociedades portuguesa e brasileira, no que tem a ver tanto com a base (as relações da produção) como com a superestrutura (organização, cultura, etc.), consagrando mais tempo ao ensino da literatura.

Ressalte-se que, enquanto o item a) é um objetivo natural de todo ensino de línguas estrangeiras a um nível universitário, o item b) tem uma clara inspiração marxista, típica da época na Europa, na sua referência às relações de produção e à superestrutura, implicando que o aprendizado da língua é a chave em relação à infraestrutura e à superstrutura de uma sociedade. Contudo, este viés progressista não foi contra as ideias de Sletsjøe, nem desencorajou os doadores capitalistas que investiram no curso. Note-se também a importância atribuída à literatura neste plano inicial.

4. Por exemplo, Dagbladet 9 de outubro de 1967.

5. Mais tarde seguiu a carreira de professor de linguística geral na Universidade de São Paulo. 


\subsection{Organização do português na faculdade}

No início, o português fazia parte do Romansk institutt (Instituto das Línguas Românicas). Depois de várias reorganizações, o português passou para o Institutt for litteratur, områdestudier og europeiske språk, ILOS (Instituto de Literatura, Estudos de Áreas e Línguas Europeias) em 2005. O ILOS é um instituto grande, constituído por muitas disciplinas heterogéneas (línguas românicas, eslavas e germânicas, literatura e estudos de áreas), em que, além de linguistas e literários, também trabalham historiadores e cientistas sociais nos estudos de área. ${ }^{6}$

\section{UM CURSO COMO OS OUTROS}

\subsection{Os professores}

Como combinado, depois dos primeiros cinco anos, o leitorado foi convertido numa posição permanente, financiada por completo pela universidade. O concurso abriu em 1972, e Kåre Nilsson, um dos primeiros a fazer mestrado em português na Noruega, foi nomeado para o cargo. Durante muitos anos, Nilsson foi o único professor de português. (Leif Sletsjøe reformou-se em 1975.)

No entanto, em 1988, houve duas contratações: Anne Sletsjøe (1951-), ${ }^{7}$ doutorada em literatura lusófona depois de ter sido estudante de doutoramento num programa para fomentar estudos de literatura brasileira, foi chamada para ser professora de literatura (professora catedrática desde 2002), com obrigação de dar aulas e orientação da literatura brasileira - uma tarefa que mais tarde foi generalizada para se referir à literatura lusófona como um todo. Birte Stengaard (1953-) entrou em 1988 como professora catedrática de espanhol, mais tarde tendo o seu título mudado para professora de filologia ibero-românica, uma formalização do facto de que ela também dava aulas e orientação sobre português antigo e história da língua portuguesa. Além disso, vários assistentes, suplentes e leitores temporários deram aulas de língua e de literatura e cultura dos países lusófonos.

Em 2005, uma leitora foi contratada a tempo parcial, 70-80\%. 50\% pago pelo então Instituto Camões e 20-30\% pelo Instituto. A partir de 2011, foi contratada pelo ILOS apenas por 20\% para dar aulas de iniciação à língua.

Nilsson reformou-se em 2008. Como sucessora, foi nomeada Diana Santos (1962-), em 2011 (professora catedrática desde 2012), pesquisadora portuguesa com muita experiência de processamento de linguagem natural, português em especial, e da pesquisa linguística (semântica, linguística contrastiva e tradutologia). ${ }^{8}$ Anne Sletsjøe reformou-se em 2012, e Birte Stengaard em 2018. Não foram contratados sucessores para nenhuma das duas, facto ao qual iremos voltar em breve.

\subsection{Os estudantes e os exames}

Numa entrevista ao maior jornal da Noruega na altura, Aftenposten, Martin Indregard afirmou, em 1969: "O português é uma nova disciplina na universidade a partir do outono. Temos doze estudantes nas cadeiras de língua, o que pode ser considerado muito bom para um início." (Aftenposten 14 de março de 1969.)

A afluência de estudantes manteve-se, e subiu com o interesse crescente por Portugal, sobretudo depois da Revolução dos Cravos, em 1974, e a subsequente independência das antigas colónias. Durante os anos 1970-1988, houve, em média, 10 estudantes de português a todos os níveis. Antes da reforma de 2003, 77 estudantes tinham feito bacharelato ("mellomfag") em português e mais 74 fizeram exames de um semestre só ("semesteremne"), 10 estudantes concluíram o mestrado ("hovedfag"), e mais dois fizeram mestrado da língua ou literatura portuguesas em outros institutos, além de pelo menos três terem feito um exame mais extenso do que o mestrado, o "magistergrad".

Depois da reforma de 2003, 7 estudantes fizeram o novo mestrado ("master") do português e pelo menos 13 o bacharelato novo ("bachelor") até 2019. Contudo, as estatísticas nesta área não são nada claras. ${ }^{9}$ Durante os dois anos, a partir de 2014, em que existiu o "årsenhet" (um exame de português depois um ano só de estudos), 12

6. Em inglês, "área studies", ou seja, uma mistura de história, política, geografia, economia, etc., associada a uma região.

7. A filha de Leif Sletsjøe.

8. Veja-se secção 6.

9. Veja-se secção 11.1 
estudantes obtiveram essa qualificação. Também outros estudantes tiveram várias cadeiras de português como parte de outros bacharelatos e mestrados.

\subsection{0 ensino}

Já durante os primeiros anos, a oferta de cadeiras era sobre a prática e a teoria da língua portuguesa em todos os níveis, sobre literatura e cultura lusófona, e, durante o primeiro ano a seguir à reforma de 2003, foram lançadas cadeiras de bacharelato sobre os assuntos seguintes:

- Língua portuguesa, iniciação A e B

- Iniciação à literatura lusófona

- Iniciação à cultura portuguesa e brasileira
- Língua/linguística portuguesa

- História da língua portuguesa A e B

- Literatura portuguesa moderna

- Linguística ibero-românica

Em nível de mestrado, cadeiras também foram criadas:
- História da língua portuguesa com explicação de textos em latim vulgar
- História da literatura de Portugal na Idade Média
- Sociolinguística do português
- Literatura lusófona dos séculos 19-21
- Filologia portuguesa
- Literatura lusófona dos séculos 16-18
- Tradutologia portuguesa
- Literatura lusófona dos séculos 13-15
- História da linguística portuguesa
- Teoria de literatura lusófona
- Linguística portuguesa
- O romance histórico, séculos 18-21
- Textos em português da Idade Média
- A poesia nos séculos 16-19
- Português do Brasil
- O teatro nos séculos 16-18
- Ensaios nos séculos 18-21
- Relatórios de viagens, séculos 16-18
- Crónicas e literatura didática nos séculos 13-15

No conjunto, 32 cadeiras, embora algumas destas fossem de leitura acompanhada (sem aulas). No entanto, em 2012, existiam 60 cadeiras, o que testemunha grande diligência da parte do corpo docente para proporcionar um estudo completo em português.

\section{ENSINO PARA QUEM?}

Nilsson (NILSSON, 1998) classifica os estudantes em três categorias:

1) Os que veem português como "instrumento", que precisam de saber português e conhecer a cultura lusófona para estudar uma outra disciplina (antropologia, silvicultura, etc.) ou para desempenhar uma tarefa específica.

2) Os que têm uma ligação pessoal ao mundo lusófono, laços de amizade ou de família.

3) Os linguistas "puros", que escolheram português por interesse pela língua em si. Entre eles há alguns que se interessam especialmente pelos aspetos teóricos ou históricos da língua, e/ou que consideram estudar português como parte do estudo de filologia românica ou linguística.

Esta classificação pode ser elaborada para identificar vários subgrupos. Os estudantes da segunda categoria podem, por exemplo, ter motivos e/ou pré-condições diferentes: Alguns têm o português como língua materna vindo em geral dum país lusófono - e querem simplesmente obter um reconhecimento académico ou documentação da sua capacidade linguística. Outros são descendentes de angolanos, brasileiros, caboverdianos, moçambicanos, portugueses, etc., que querem aprender ou aperfeiçoar a língua dos antepassados. Ainda outros são pessoas que tencionam aprender do início a língua duma pessoa com a qual têm uma relação pessoal. Além disso, há bastantes estudantes que fizeram intercâmbio num país lusófono no ensino secundário. Como se vê, trata-se de um grupo bastante heterogéneo - com objetivos e interesses diferentes e, sobretudo, com conhecimentos prévios muito diferentes. 


\section{PROBLEMAS DO ENSINO}

\subsection{Falta de conhecimentos prévios}

Tal como no caso de outras línguas estrangeiras que não se ensinam na escola secundária norueguesa, os estudantes de português, em geral, não têm conhecimentos prévios da língua, se exceptuarmos o caso dos alunos que têm o português como língua materna. Estes podem, aliás, dificultar a aprendizagem dos outros estudantes, intimidando-os e até levando-os a desistir de continuar os estudos.

Uma maneira de resolver o problema da falta de conhecimentos prévios é oferecer cadeiras especiais para principiantes. Cadeiras introdutórias foram oferecidas entre 1978 e 1993, substituídas por razões económicas por um teste diagnóstico para determinar se o estudante precisava de uma cadeira de preparação fora da universidade antes de assistir às aulas. Mais tarde, uma cadeira introdutória foi incluida no novo bacharelato.

\subsection{As variantes do português}

Não só conhecimentos prévios são importantes, o caráter destes conhecimentos também é. Sendo uma língua pluricêntrica (MUHR, 2015), o ensino do português deveria, em termos ideais, ser feito nas duas variantes dominantes, a do Brasil e a de Portugal. Contudo, isto não foi possível por causa de um corpo docente diminuto. Kåre Nilsson, que ensinou de 1972 a 2008, escreve que dava aulas em português de Portugal, naturalmente aceitando português do Brasil quando utilizado duma maneira consistente (NILSSON, 1998). Diana Santos, a presente professora, ensina as duas variantes (SANTOS, 2016). Durante vários períodos houve assistentes com uma relação natural ao português do Brasil.

\subsection{0 papel da literatura}

Antes da contratação de Anne Sletsjøe, em 1988, eram apenas assistentes que davam cadeiras sobre literatura lusófona. Por isso, Anne Sletsjøe representou uma consolidação importante da disciplina. Não só por ter grande competência na literatura e cultura brasileiras, nem apenas porque pela primeira vez uma especialista altamente qualificada dava aulas da literatura duma maneira regular, mas porque completava a parte linguística da disciplina. O estudo da literatura era cem por cento à base de textos originais em português, e assim tratado como uma parte integrante do estudo da língua. Porque no ensino duma língua estrangeira ao nível universitário a literatura e a ficção não são só uma questão de estética, que tem um valor incontestável em si, mas também tem utilidade prática: como documentação do uso prático da língua, mas sobretudo para iniciar os estudantes na cultura da sociedade linguística em questão. Estudar a literatura ajuda o estudante a adquirir uma competência comunicativa. No caso do português, a literatura tem um papel especialmente importante representando uma ligação entre os lusofalantes de todos os continentes.

\section{PESQUISA}

Quanto à formação de pesquisadores, duas estudantes fizeram o "magistergrad" em filologia românica em 1981 e em 1997. Uma delas, Birte Stengaard, também foi a primeira depois de Leif Sletsjøe a fazer doutoramento em 1988 (O assunto da tese tratava parcialmente do português.) Nos anos a seguir, Anne Sletsjøe (1993), AnnMarie Mathiassen (2002) e Aino Rinhaug (2007) doutoraram-se em literatura, enquanto a linguista Kristine Eide se doutorou em 2006, com um estudo diacrónico sobre a sintaxe do português.

Além das teses, a pesquisa, levada a cabo pelos professores do português antes de 2011, desenvolveu-se tal como era costume na área das letras - em geral na forma de projetos individuais, na maioria dos casos com livros ou artigos como resultado - sobre autores de Portugal, Brasil, Moçambique e Angola, sobre a história do português, a sintaxe e estrutura de informação em português antigo e moderno, sobre linguística de corpus e como ensinar o português como língua estrangeira aos estudantes noruegueses. Entre as publicações, destaca-se uma obra lexicográfica, o Norsk portugisisk ordbok, um dicionário extenso norueguês-português - o primeiro no seu género publicado na primeira versão em 1979 (NILSSON, 1979). 
A contratação de Diana Santos trouxe uma maneira de fazer pesquisa e desenvolvimento diferente das atividades tradicionais numa faculdade de letras, dada a sua experiência anterior de grandes projetos de linguagem natural realizados em cooperação estreita com outros pesquisadores, em geral de Portugal ou do Brasil, resultando em sistemas e recursos electrónicos para além de monografias e artigos. Depois de começar a trabalhar no ILOS, iniciou vários outros projetos relativos à língua portuguesa, apostando numa infraestrutura computacional de ensino de língua e desenvolvendo ferramentas didáticas e de pesquisa.

\section{COLABORAÇÃO INTERNACIONAL}

Um acordo cultural entre a Noruega e Portugal foi ratificado só em 1977. Durante as negociações, a Noruega exprimiu o desejo de Portugal mandar outro leitor à Universidade de Oslo. Porém, este desejo não se materializou exceto na forma de alguns projetos passageiros. Por outro lado, o Brasil nunca mandou leitores à Noruega, com a exceção duma curta estadia de Norma Seltzer Goldstein em 1997. ${ }^{10}$

Mesmo assim, a 5 de setembro de 1995, a Universidade de São Paulo e a Universidade de Oslo celebraram um acordo que implicava troca de pesquisadores e cursos intensivos aos níveis de mestrado ou doutoramento na área do português. Infelizmente, este acordo foi extinto depois de poucos anos por falta de financiamento.

Em 2008, os professores de estudos latino-americanos negociaram com a Universidade Federal de Ouro Preto (UFOP) um acordo sobre troca de estudantes na área de língua portuguesa e da cultura e história do Brasil.

Existe também um acordo com a Universidade Eduardo Mondlane, em Maputo, e Fátima Marinho, professora catedrática da Faculdade de Letras da Universidade do Porto informa, em comunicação electrónica no dia 4 de fevereiro de 2019, que existe um acordo no âmbito do programa europeu de mobilidade de estudantes Erasmus desde o ano escolar 2004/2005.

Além destes acordos, ligados especialmente à aprendizagem da língua portuguesa, existiam em 2019 no conjunto 6 acordos a nível global entre a Universidade de Oslo e universidades no Brasil: a Universidade Federal de Minas Gerais (Belo Horizonte), a Universidade do Estado de Santa Catarina (Florianópolis), a Universidade Federal de Santa Catarina (Florianópolis), a Pontifícia Universidade Católica do Rio de Janeiro, a Universidade Federal de Ouro Preto e a Universidade de São Paulo.

\section{PORTUGUÊS PARA QUÊ?}

\subsection{Português na sociedade norueguesa}

$\mathrm{Na}$ Noruega, um exame de português não qualifica para uma profissão determinada, tal como professor da escola secundária. Só duma maneira indireta, como parte dum bacharelato ou mestrado que inclua outras disciplinas que qualifiquem para ensino secundário. Por outro lado, uma pessoa com mestrado em português fica qualificada para posições onde não há exigência de um exame de educação específico, e, com certeza, em especial para posições que têm uma relação com os países lusófonos. Na prática, quando faz parte duma combinação de disciplinas de outras faculdades, tal como ciência política ou economia. Mas o que sempre fez falta foi a aceitação de português como língua estrangeira nas escolas norueguesas.

\subsection{Português nas escolas?}

A questão de incluir o português como língua estrangeira nas escolas norueguesas foi levantada pelo lado português durante as negociações do acordo cultural, e nunca foi recusada oficialmente pelas autoridades norueguesas. Todavia, sem resultado. Infelizmente, até há poucos anos os professores universitários de português não mostraram interesse ativo neste assunto. Contudo, esta atitude mudou com Diana Santos, cujas intenções coincidiram com as do Centro para o Fomento dos Estudos das Línguas Estrangeiras, Fremmedspråksenteret ${ }^{11}$. Já em 2014 esse centro

10. Cf. GOLDSTEIN (1998).

11. A partir de 2018: Nasjonalt senter for engelsk og fremmedspråk i opplæringen. 
concluiu um acordo de intenção com o Instituto Camões ${ }^{12}$ para fomentar o português e desenvolver recursos de aprendizagem. O resultado foi a introdução do português em duas escolas secundárias no ano escolar 2013-14, e, a partir do outono de 2017, também começou a ser oferecido um curso de português na Internet. Para despertar o interesse pelo português entre os alunos das escolas secundárias, Diana Santos redigiu a brochura Portugisisk i verden, 'O português no mundo', integrada na série dedicada a línguas estrangeiras do centro (SANTOS, 2015). Além disso, congregou um grupo de redação de um manual de português destinado aos alunos sem conhecimentos prévios, baseado nos planos governamentais escolares, que publicou uma introdução ao português fundamental, tendo em conta as variantes do Brasil, de Moçambique e de Portugal (LONDRIM et al., 2017).

Mas estas iniciativas não criaram um efeito decisivo nem nas escolas, nem em relação à procura do português na Universidade de Oslo. Por exemplo, o ILOS nunca mencionou o português nas visitas às escolas que faz regularmente para fomentar o interesse pelas línguas estrangeiras. Explicam isto porque a instância académica responsável pela formação pedagógica de futuros professores, o Instituto de Formação de Professores e de Pedagogia Escolar ("Institutt for lærerutdanning og skoleforskning", ILS), não reconhece a formação em português como uma forma de entrada nos estudos pedagógicos para ser professor na escola secundária. Assim, existe a situação estranha de que a instância estatal norueguesa para promover o estudo de línguas estrangeiras no ensino básico e secundário se esforça por fomentar o ensino do português nas escolas, ao mesmo tempo que a instância de autorização formal de professores se opõe - além do mais, contra as intenções de aumentar o interesse de português da parte do próprio Governo:

Os contactos mais frequentes com o Brasil falam a favor duma aposta maior no português. (Stortingsmelding 'Livro branco' 25, 2016-2017, Humaniora i Norge 'A situação das Letras na Noruega' p. 58)

Este interesse tem por base três fatores. Cultura, indústria e pesquisa.

\subsection{A importância para a Noruega}

A importância cultural é evidente: Além de dar acesso a uma literatura grande e rica, a competência em português representa uma ferramenta para conhecer uma cultura grande e multifacetada, espalhada por cinco continentes.

Quanto ao interesse do setor empresarial no mundo lusófono, já não se concentra só nos transportes marítimos e na importação de café. Os investimentos na extração de gás e de petróleo ganharam uma grande importância, assim como fenómenos novos como o turismo de massas, a assistência aos países em vias de desenvolvimento e a proteção da selva. Portugal e os países lusófonos da África continuam a ser relevantes, mas sobretudo o Brasil veio a tornar-se um parceiro de negócios de grande importância para a Noruega (energia, petróleo, gás e servicos técnicos, fertilizantes, alumínio, café, peixe e produtos agrícolas, adubo químico, por exemplo). No fim de contas, o que Leif Sletsjøe escreveu nos seus artigos em 1949 e 1953, e a fundamentação de Øivind Lorentzen A/S em 1967, ainda hoje têm valor. É preciso saber português. ${ }^{13}$

Também no que tem a ver com tecnologia, pesquisa e desenvolvimento no Brasil o interesse das instituições norueguesas é grande. É importante ter acesso aos resultados de pesquisa publicados em português, sobretudo na área das ciências. ${ }^{14}$ Da mesma importância é um desejo de participar ativamente nos projetos, o que é posto em destaque por todas as delegações numerosas de ministros, reitores de universidades e industriais noruegueses que visitaram o Brasil durante os últimos anos (em 2003, 2011, 2014, 2015 e 2016). Mas, para citar Egil Trømborg (decano da Universidade Metropolitana de Oslo), um dos participantes, quando estava de volta na Noruega: "(---) existe um desafio grande em relação à cooperação com o Brasil - a língua, ou mais precisamente: $O$ português. ${ }^{115}$ Como é que este interesse geral da língua portuguesa se materializa no mundo académico? Vamos primeiro dar conta da situação no início do novo milénio.

12. Agora Camões - Instituto da Cooperação e da Língua.

13. Um exemplo é a empresa K. Lund Offshore, ligada à extração de gás e petróleo com grandes atividades no Brasil. Em reportagem publicada na revista eletrónica da Universidade de Stavanger, o diretor Gaute Jørpeland diz "Sem um conhecimento básico da língua [o português], não se tem sucesso no Brasil." Cf. https://www.uis.no/om-uis/nyheter-og-presserom/utvikler-ipad-kurs-i-portugisisk-for-naringslivetarticle44993-8108.html? articleID=44993\&categoryID=8108. Acesso em 10 de outubro 2020.

14. Veja-se, por exemplo, Gronstad (2015) e Holm et al. (2015).

15.Cf. Tønnessen (2015). Também como diz a informação na rede interna da Universidade de Oslo sobre a Universidade de São Paulo: "A língua de ensino é o português". https://www.uio.no/studier/utveksling/avtaler/sor-amerika/brasil/sp-saopaulo/uio.html. Acesso em em 1 de janeiro 2019 


\section{O CURSO DO PORTUGUÊS NO INÍCIO DOS ANOS 2000}

Na proposta de prioridades e plano de recrutamento do ILOS para o período 2007-2011 (2006), lê-se sobre "vantagens competitivas em relação a outros estabelecimentos universitários":

Único instituto nos países nórdicos abrangendo o espanhol e o português em toda a largura temática e geográfica, do ponto de vista de pesquisa e de ensino. A Universidade de Oslo é também a única universidade nórdica que tem professores de língua e da literatura em posições fixas. (p. 39)

E a seguir:

A secção [de línguas ibero-românicas] pode contribuir para assegurar a coesão científica do instituto por meio de competência da filologia românica, latim vulgar, tradutologia, e da literatura e todos os aspetos das áreas do mundo ibero-românico (p. 40)

\section{O ENFRAQUECIMENTO DO PORTUGUÊS COMO DISCIPLINA UNIVERSITÁRIA}

\subsection{A cátedra de literatura que desapareceu}

Desde a contratação pela Universidade de Oslo de Anne Sletsjøe, em 1988, houve duas posições fixas de português, uma de língua e uma de literatura, além da leitora (20\% depois de 2011) e da professora de filologia iberoromânica. Mas a professora catedrática de literatura reformou-se inesperadamente em janeiro de 2012, e conforme uma regra recente da faculdade não houve automaticamente um concurso para sucessor. $\mathrm{O}$ cargo devia ser avaliado sem preconceitos, como se se tratasse duma posição nova. Ao mesmo tempo, Karen Gammelgaard, até então professora catedrática da língua checa, foi contratada como chefe do Instituto, um cargo estritamente administrativo.

\subsection{Formalidades e qualidade do ensino}

Aconteceu que, em fevereiro de 2013, o Órgão Nacional de Qualidade na Educação ("Nasjonalt organ for kvalitet i utdanningen", NOKUT) anunciou uma inspeção sobre a atividade educativa do ILOS, em particular sobre os 'Estudos da América Latina', um dos cursos oferecidos no Insttituto.

Segundo NOKUT, os critérios são os seguintes para cursos de mestrado: pelo menos um professor catedrático, pelo menos $50 \%$ dos professores sem cargos noutras instituições, um corpo docente constituído por um número suficiente de pessoas com competência adequada, que tenham resultados documentados de alto nível e que tenham uma história de cooperação com parceiros nacionais e internacionais. Como se vê, 'qualidade' definida basicamente em termos quantitativos e duma maneira puramente formal.

NOKUT considerou os Estudos Latino-Americanos como um curso frágil, dado o facto de só ter um professor dedicado formalmente à disciplina na altura. Faltavam recursos, e a publicação científica também foi considerada fraca. (O professor tinha dado prioridade ao desenvolvimento pedagógico a fim de consolidar um estudo novo.)

Nas atas do ILOS e da Faculdade de Letras, as menções ao processo que resultou da inspeção do NOKUT são fragmentárias, o que também é o caso nos acontecimentos que se seguiram - em contraste com o impacto que essa inspeção causou, não só para os Estudos Latino-Americanos, mas também para a questão da literatura lusófona - e, no fim, para a própria existência do português como curso.

\subsection{A nova secção - SPLA}

O ILOS escolheu satisfazer os supostos requisitos de NOKUT criando uma nova "secção" administrativa, Espanhol, Português e Estudos da América Latina ("Spansk, portugisisk, og Latin-Amerika-studier", SPLA). Quer dizer, juntaram todos os recursos de dois estudos filológicos de línguas diferentes e uma disciplina já heterogénea (geografia, historia, sociologia, etc.) para constituírem uma só secção, baseada na proximidade e afinidade genética das línguas. Do ponto de vista científico, um grupo verdadeiramente inconsistente. Contudo, o padrão era óbvio: Alguns anos antes, ILOS tinha criado algo semelhante, Estudos da Europa Central e dos Balcãs, constituídos por bósnio-croata-sérvio, polaco e checo. Na altura, os professores protestaram, entre eles, a futura chefe de ILOS. 
Todas as objeções contra o estabelecimento de SPLA foram rejeitadas. O italiano, ao contrário, que na altura também tinha apenas dois professores, nenhum deles catedrático, continuou como secção a par do francês. O motivo racional para organizar as línguas ibero-românicas duma maneira radicalmente diferente nunca foi dado.

\subsection{A dança das cadeiras}

Ao mesmo tempo, foi decidido um novo plano de posições docentes para 2014-2018. No que tem a ver com SPLA, o plano era

1 professor com obrigação de ensinar num espetro largo - na condição de que os professores do setor definam um cargo que junte e individualize o campo, em particular na forma de um estudo robusto.

A seguir na secção 'A função estratégica das contratações':

Professor na área espanhol/português/América Latina

O cargo vai ser concretizado em cooperação com os professores do setor de maneira que solidifique as tarefas de pesquisa a que os professores do setor se queiram dedicar. O cargo vai contribuir para clarificar e unificar a competência extensa e única dentro da área de espanhol/português/América Latina.

Esta descrição é vaga e contém contradições, dado o contraste inerente entre "individualizar" e "ensinar num espetro largo", etc. Professores de áreas que tinham pouco ou nada em comum deviam unir-se, e cooperar a fim de tornar visível a disciplina (qual disciplina?).

Então, e sem a ter discutido com os professores do setor, a liderança do ILOS apresentou uma nova proposta de denominação dum cargo: "Novo cargo que integre e perfile o setor. Sugestão da equipa de liderança: professorado de cultura de texto brasileira."

Os membros da seç̧ão não aceitaram, já que ninguém sabia o que era 'cultura de texto brasileira', não sendo uma disciplina aceite nem nas universidades brasileiras nem nas portuguesas.

Assim, não se podia esperar muitos interessados qualificados, e seria possível para a liderança contratar qualquer pessoa que soubesse alguma coisa sobre o Brasil. Se, ao contrário, um concurso de literatura e cultura lusófonas com ênfase no Brasil tivesse sido aberto, que era ao que "os professores do setor" se queriam "dedicar", com certeza muitas pessoas competentes se candidatariam. Outra vantagem fundamental dum professorado "tradicional" de literatura seria que uma pessoa competente automaticamente saberia português, algo essencial num corpo docente mínimo. Uma pessoa que ensinasse sobre o Brasil noutra língua (por exemplo espanhol ou inglês), não só seria incapaz de participar no trabalho dos exames, mas também não poderia ensinar aos estudantes como perceber nem escrever em português sobre o conteúdo da cadeira.

Depois de alguma discussão com a liderança do Instituto, em 2014, a secção SPLA propôs: "professor de literatura e cultura lusófonas, dando relevo ao Brasil". Infelizmente, a chefe do Instituto fez saber logo depois, que esta proposta tinha sido recusada pelo órgão relevante da faculdade, alegando que "dando relevo ao Brasil" faltava precisão. Contudo, não existem vestígios duma decisão dessas nas atas deste órgão.

O processo teve que recomeçar de novo no ano seguinte, e, em setembro de 2015, pode ler-se nas atas duma reunião do conselho diretivo que

O conselho diretivo decide que os requisitos de uma abertura de concurso do cargo classificado número 1 são considerados satisfeitos, e um professorado é para ser anunciado logo que seja possível.

O conselho deu a esta proposta a prioridade no plano de recrutamento do ILOS, enquanto um professorado de italiano ficou em segundo lugar. No entanto, em dezembro do mesmo ano, o conselho diretivo soube pela chefe do Instituto que o cargo de português não tinha sido aceito pela faculdade, porque "Os requisitos dum tal cargo não estavam satisfeitos." Na mesma reunião, os chefes da faculdade tinham decidido pôr o professorado em italiano no primeiro lugar do plano de recrutamento. ${ }^{16}$

Durante este processo, os professores do setor nunca foram consultados pela liderança do Instituto, e os membros foram expressamente proibidos de contactar o decano da faculdade. Tudo tinha que acontecer por via

16. Veja-se Engh (2021). 
oficial no sentido mais estrito. É provável que os argumentos em favor de manter o cargo da literatura lusófona nunca tenham chegado sequer a ser apresentados ao decanato.

\subsection{0 curso de um ano}

No meio deste processo, a liderança do ILOS ordenou a abertura dum curso suplementar em português de um ano só, o "årsenhet" (2014), a fim de fazer apelo aos estudantes que queriam se especializar numa outra matéria, mas também alegadamente para facilitar um novo cargo da literatura lusófona. Infelizmente, tornou-se impossível, na prática, manter um ensino como deve ser para o bacharelato em paralelo com o "årsenhet". Depois de dois anos, o corpo docente pediu uma suspensão de um ano. Contudo, o ILOS simplesmente pediu o encerramento do curso à Faculdade de Letras. A professora de português soube do encerramento por acaso - ao ler o jornal interno da Universidade de Oslo, Uniforum.

\subsection{Fim do ensino da literatura}

Numa última tentativa, o conselho diretivo apoiou a proposta dos professores do setor de restabelecer a cátedra de literatura em 2016. Sem resultado.

Durante o processo inteiro para definir um cargo "novo" para substituir a antiga cátedra da literatura lusófona, o ensino tinha estado a cargo de suplentes que, aliás, não tinham o direito de mudar o currículo ou fazer mudanças de vulto nas cadeiras, impossibilitando atualizações. Porém, depois da proposta de um professorado da literatura lusófona ter sido definitivamente rejeitada, já não era legal contratar um suplente (dum professorado inexistente). Não houve aulas de literatura depois desta altura, todo o ensino nesta área acabou, e os estudantes foram obrigados a procurar aulas de literatura no estrangeiro, na prática em Portugal ou no Brasil.

Este facto prejudicou o português como disciplina de várias maneiras. Não só era uma decisão duvidosa do ponto de vista educacional, também destruiu a confiança dos estudantes na disciplina - e no Instituto.

Remeter os estudantes para procurar ensino no estrangeiro a fim de adquirir conhecimentos da literatura numa língua estrangeira representa uma "internacionalização" mal percebida. No estrangeiro, um estudante ou tem que assistir a uma cadeira para todos os estudantes estrangeiros, e por isso correspondentemente superficial, ou assistir a uma cadeira para os estudantes nacionais, que já têm uma competência completa da língua, e que, além do mais, conhecem a literatura do currículo da escola. Por isso, é sempre melhor para os estudantes ter cadeiras de literatura como uma parte integrante do ensino da língua estrangeira, pelo menos na fase inicial (bacharelato), na prática numa universidade na Noruega. Mais tarde, os estudantes devem passar algum tempo num país onde se fala a língua, e assistir a cursos, se quiserem. Mesmo assim, uma tal estadia não pode substituir um estudo universitário completo na Noruega.

Por outro lado, o ILOS anunciou o encerramento das cadeiras de literatura depois de os estudantes terem começado o curso - perto do fim do trimestre da primavera de 2016. Isto contribuiu para uma incerteza em relação ao que podia acontecer mais tarde, uma imprevisibilidade que claramente assustou novos estudantes que poderiam escolher o curso de português. Em que ia consistir o ensino no futuro? Seria possível concluír o curso? Como era fácil de adivinhar, o resultado redundou em menos interesse, e menos estudantes. Mais tarde, a falta de estudantes foi usada como argumento pela liderança de ILOS para reduzir o ensino, e acabar completamente com o bacharelato.

\subsection{Consequências}

As duas professoras, a professora catedrática e a leitora, enfrentaram uma escolha: Ou deixar de aceitar novos estudantes de bacharelato, ou recomeçar no próximo ano letivo (a partir do outono de 2016), com um plano novo e ditado pela liderança do Instituto: Os estudantes teriam que estudar literatura no estrangeiro ou assistir na Universidade de Oslo a uma cadeira de estudos latino-americanos sobre a parte do continente onde se fala espanbol. Mesmo assim, as professoras escolheram recomeçar o ensino outra vez - na esperança de reatar o processo para obter um professorado de literatura lusófona no ano seguinte. Em vão. 


\section{O DESMANTELAMENTO PASSO A PASSO}

\subsection{Cronologia e argumentação}

Provavelmente, quem decidiu encerrar a posição da literatura definitivamente foi a chefe do ILOS, Gammelgaard. Nem a professora da língua portuguesa nem os outros membros do SPLA foram consultados.

No ano seguinte, 2017, as professoras foram informadas de que a liderança do Instituto ia discutir uma proposta de parar temporariamente a aceitação de novos estudantes de português em 2018 - um dia útil só antes de a proposta ser decidida pelo conselho diretivo e a seguir a seis reuniões em que nada tinha sido mencionado sobre uma tal medida. Como base para a discussão da reunião do conselho, a liderança apresentou um documento que continha o parágrafo seguinte:

O curso de bacharelato em português é certamente aquele cujos estudantes menos completam o curso durante o período analisado pela faculdade: Só 5 \% dos estudantes acabam (e nenhum no tempo normal).

Este documento era baseado no relatório da faculdade "ILOS. Bachelorstudier i tall 2008-2015" (ILOS. Estudos de bacharelato em números 2008-2015.) Apesar do título, o documento só contém estatística dos anos 2010-2014, e não contém o número exato de " 5 \%", mas, pelo contrário, um aviso: "A estatística ao nível dos cursos tem que ser lida com cuidado." Com efeito, contém algumas fraquezas. Por exemplo, "bacharelatos complexos"17 não foram incluídos neste documento. Contudo, o cerne do problema é a base da estatística sobre os que não completam os estudos: os que se registam ou os que efetivamente assistem a pelo menos uma aula? Os $5 \%$ mencionados no documento claramente não foram calculados com base no último. ${ }^{18}$ Além disso, nada está escrito no documento sobre causas possíveis da suposta alta taxa de abandono. Todavia, 2008-2014 foram anos extraordinários, e é fácil apontar condições que pudessem explicar um abandono durante este período: Kåre Nilsson reformou-se em 2008, e Diana Santos só foi contratada em 2011, o que quer dizer que nos anos entre 2008 e 2011 não havia um professor da língua portuguesa. Anne Sletsjøe reformou-se em 2012, e não teve sucessor, deixando de haver um professor da literatura lusófona. O cancelamento do ensino da literatura em 2016 e o processo que acabou no encerramento dos estudos latino-americanos em $2017^{19}$ também pode ter exercido um impacto negativo na taxa de estudantes que conseguiram fazer exames. Seja como for, a aceitação de novos estudantes foi parada temporariamente.

Depois da reunião do conselho diretivo, as professoras de português mandaram uma proposta à liderança para recomeçar o curso de um ano que já tinha sido encerrado temporariamente antes - para compensar, proposta essa que foi recusada.

Durante todo o outono as professoras e os estudantes tentaram entrar em contacto com a liderança do Instituto - sem conseguir. Contudo, poucos dias antes das férias de Natal de 2017 foram chamadas para uma reunião com a liderança do ILOS - só para ouvir que o bacharelato de português ia ser encerrado definitivamente a partir do ano 2019.

Pertence a esta história que, umas semanas antes, a chefe do ILOS e o decano tinham apaziguado os embaixadores do Brasil e de Portugal durante uma reunião na universidade, dizendo que não ia acontecer qualquer mudança drástica a propósito do curso de português.

Houve dois processos administrativos paralelos, um aberto, fragmentário, com o corpo docente, outro entre as lideranças do Instituto e da Faculdade, sem conhecimento do corpo docente. No âmbito do último, o subchefe do Instituto encarregado do ensino mandou uma carta à faculdade onde pediu para acabar o estudo de português. Três razões são mencionadas: poucos estudantes interessados, poucos estudantes a fazer exame, falta de professores e falta de competência nas áreas de literatura lusófona e estudos de área. Contudo, esta carta tem graves falhas no que respeita ao procedimento e solidez da argumentação.

Primeiro, o autor faz referências incorrectas às atas que tratam do assunto de parar temporariamente a aceitação de novos estudantes. Segundo, há informação errada sobre os professores. Terceiro, muitas informações sobre o ensino estão erradas. Quarto, afirma-se que "menos de 5 estudantes" completaram o bacharelato até o fim de 2017. Isto

17. Em norueguês: "fritt sammensatte bachelorgrader".

18. Estudantes que se registam sem fazer exame é um problema comum nas universidades norueguesas.

19. Os dois professores dos estudos latino-americanos saíram do ILOS em 2017. 
pode ser verdade no caso dos anos 2010-2014, um período excepcionalmente difícil. ${ }^{20}$ No entanto, vários estudantes fizeram exames durante os anos a seguir. Apenas alguns meses depois que a carta foi escrita, 8 estudantes tinham acabado o bacharelato, e até o fim do ano 2019 com certeza $13^{21}$, provavelmente mais. ${ }^{22}$ Como já mencionado, os números nesta área não são nada claros: Além das faltas e das inconsistências referidas, por causa de proteção dos dados pessoais, e também devido a problemas de categorização. Ou seja, muitos estudantes de português são capazes de se encontrar numa categoria 'disciplina não especificada' nas estatísticas da universidade, que reporta 523 indivíduos assim classificados neste período.

Um ponto final ao processo foi posto numa reunião da faculdade a 20 de abril de 2018, quando foi referida a decisão do pró-decano encarregado da educação de acabar o curso de um ano e o bacharelato de português. Os argumentos alegados foram a pouca afluência aos exames e a contenção de que o curso não satisfazia as exigências dos estudantes. Esta última afirmação, que aparece neste contexto pela primeira vez, não é documentada, e contrasta claramente com os abaixo-assinados e os artigos polémicos dos estudantes na imprensa.

Durante a fase final de todo este processo administrativo, motivos, razões e consequências foram discutidos no Uniforum, e a decisão foi altamente criticada por estudantes e numerosos académicos. ${ }^{23}$

Segundo a versão final do plano de recrutamento 2018-2022 de ILOS, aprovado pelo conselho diretivo a 28 de maio de 2018,

Antes de encerrar a disciplina, o instituto assegura que os estudantes podem estudar cadeiras de português na continuação ao nível de bacharelato e se qualificarem para o mestrado por meio de estadias em universidades no estrangeiro, (---). O português vai ser conservado ao nível de mestrado em cooperação com o espanhol, (---).

O plano não contém nenhuma vaga para a área do português. Por outro lado, ILOS criou duas saídas novas: Um curso de 40/50 créditos (com efeito um dos elementos do antigo curso de bacharelato) - tornando o português um curso auxiliar - e uma nova versão do mestrado "em cooperação" com o espanhol. Nenhum pormenor concreto do conteúdo do último é conhecido. Contudo, os critérios de qualificação são claros: os estudantes podem qualificarse "(---) fazendo cadeiras em universidades no estrangeiro, (---), e afirmam: "O (novo) bacharelato de português mais focado significa que vai ser possível garantir tempo adequado para pesquisa e desenvolvimento pessoal."

Além do facto que já não vai haver um bacharelato de português, esta declaração é peculiar, dado que pesquisa na área de português é impedida ao nível do Instituto e da Faculdade como área não prioritária.

\subsection{0 processo e a alternativa}

Mesmo durante a fase final deste processo, às professoras foi negado o direito de apresentar as suas opiniões e retificar informação errada ao decano e ao reitor da universidade. Todo o processo foi repreensível. Houve um grande desacordo sobre o que na realidade foi dito durante as poucas reuniões. Além disso, uma parte surpreendente do processo aconteceu por via oral e mais ou menos de passagem, e mesmo as decisões não foram sempre documentadas nas atas. De mais a mais, a argumentação da liderança, como mostrei acima, foi inconsistente e mal fundamentada. Burocracia mal feita à parte, a falta de fundamento académico da redução do português apresentou-se em várias maneiras, por exemplo nos comentários ao novo plano de corpo docente do ILOS do período 2018-2022:

A fim de realizar o objetivo de consolidar a disciplina de espanhol para dar ensino de qualidade a todos os níveis, é preciso conferir a disciplina mais um professorado principalmente da língua espanhola. Talvez o professorado deva ser destinado à sociolinguística e à história da língua, entre outras coisas a fim de assegurar um leque de qualidade de cadeiras ao nível do mestrado para os estudantes de espanhol e de português.

Claramente a área da sociolinguística aplicada ao espanhol é completamente irrelevante para o ensino do português, ou seja, um professor especialista em sociolinguística espanhola não poderia ensinar nenhuma disciplina do curso de português.

20. Veja-se secção 11.1

21. Segundo o Centro Norueguês de Dados de Pesquisa ("Norsk senter for forskningsdata", NSD), 6 e provavelmente mais alguns tinham concluído o bacharelato antes do início de 2018, e ao fim do ano, o secretariado do ILOS indica pelo menos 13.

22. Também não foram mencionados os 12 que fizeram o curso de um ano e os 3 de mestrado (com outros 3 em vias de finalização).

23.. Uma lista extensiva de contribuições prós e contras de português como curso da Universidade de Oslo encontra-se em http://folk.uio.no/ dssantos/KampForPortugisisk.html. Acesso em 1 de janeiro 2019. 
Em vez de levar o curso de português ao desmantelamento, o Instituto deveria em primeiro lugar ter mantido o corpo docente como era, quer dizer, devia ter aberto concurso para um sucessor na cátedra da literatura portuguesa. Assim, a universidade poderia não só ter evitado a imprevisibilidade que o término súbito da cátedra de literatura provocou, criando entre os estudantes um sentimento generalizado de insegurança sobre o futuro do português, mas também ter criado um curso mais interessante. Convém citar umas palavras do ensaio de Leif Sletsjøe (1953): "(---) um ensino melhor tem em geral como resultado que o interesse dos estudantes cresce." Além do mais, o Instituto deveria ter-se esforçado por arranjar mais estudantes - para aumentar a "produção de créditos" e a proporção de conclusão do curso, deveria ter tomado iniciativas para assegurar financiamento extraordinário e, por último, deveria ter feito acordos e entrado em cooperação verdadeira e continuada com os países lusófonos, reanimando os acordos "adormecidos" e aceitando as propostas de cooperação. ${ }^{24}$

\subsection{A situação atual}

Como se esperava, o processo administrativo refletiu-se no número de cadeiras. Não são fáceis de encontrar na lista oficial de programas da Universidade, mas quando se procura na página dos estudantes da faculdade, encontramse 4 cadeiras em 2019. Contudo, uma delas foi cancelada pela administração apesar de haver estudantes interessados. O contraste com todas as cadeiras que os estudantes podiam escolher em 2012 é enorme.

O português tornou-se "invisível" e não vai contar na prática, e um mestrado em espanhol $e$ português não tem futuro. Daqui a pouco tempo, poderá não haver mais estudantes de bacharelato qualificados para a entrada num estudo de mestrado. É um erro pensar que todos os estudantes têm interesse em estudar as duas línguas se o espanhol for obrigatório, ou que os estudantes interessados em português vão para o estrangeiro para ter ensino da literatura numa fase inicial dos estudos. (A experiência dos últimos anos é que ninguém foi!)

Quanto à formação de pesquisadores, o ILOS decidiu, já em 2013 encerrar a possibilidade de fazer o grau de philosophiae doctor (Ph.D.) na área. Assim, não vai haver mais estudantes de Ph.D. de português com financiamento norueguês, e até recentemente o ILOS recusou-se mesmo a acolher estudantes com financiamento do Brasil ou de Portugal, que queriam ter Diana Santos como orientadora.

\section{0 DESMANTELAMENTO EM PERSPETIVA}

\subsection{Contraste com a política oficial de conhecimento}

A "aposta no português" do livro branco do Governo da Noruega já foi mencionada. Também é interessante que o desmantelamento do português como disciplina universitária começou ao mesmo tempo que as grandes delegações norueguesas foram ao Brasil. O seu objetivo era discutir a cooperação no setor da pesquisa e de ensino superior; promover a educação superior na Noruega; propor as instituições de pesquisa norueguesas como parceiros de cooperação e criar redes e estabelecer contactos. ${ }^{25}$ Como a Universidade de Oslo e o governo norueguês querem aumentar o contacto, prometer educação superior na Noruega e criar redes de contacto para cooperação, etc. quando ao mesmo tempo reduzem drasticamente um curso necessário para a sua realização, é difícil de perceber.

\subsection{Contraste com a antiga liderança da universidade}

Numa situação semelhante há alguns anos - quando a língua italiana parecia estar ameaçada como estudo - as lideranças da Universidade de Oslo e da Faculdade de Letras tiveram uma opinião diferente. O então reitor disse ao jornal Aftenposten:

A universidade toma a sério a responsabilidade das disciplinas linguísticas. Quando o Aftenposten sugeriu que estas disciplinas dependem totalmente dos resultados económicos finais, não é verdade. (---) Também não há razão para fazer uma descrição assustadora de pequenas disciplinas linguísticas terminadas ao primeiro défice. Não se trabalha assim na Universidade de Oslo. Aqui pensa-se a longo prazo (Aftenposten 26 de março de 2007.)

24. Entre outras coisas, Portugal ofereceu apoio em 2017 na forma de um curso de literatura, que foi recusado pela liderança da faculdade. 25. Veja-se secção 8.3 . 
Os então decanos disseram também ao Aftenposten a propósito do mesmo assunto: "Conhecimento de outras línguas e culturas é fundamental na sociedade global." (Aftenposten 20 de março de 2007.)

Contudo, os seus sucessores tinham outras atitudes, não só no que tem a ver com disciplinas específicas, mas também em relação à gestão da universidade em geral. E não só. Respondendo à pergunta se o desmantelamento do curso de português não era contrário à política académica do governo atual, o Ministério de Pesquisa e de Ensino respondeu que certamente o Instituto e a Universidade de Oslo tinham examinado a importância do português para a sociedade norueguesa antes de chegar a uma decisão. ${ }^{26}$ Ninguém ouviu falar dum tal exame. É sintomático que o Instituto, no mesmo ano que o português faz 50 anos na Universidade de Oslo, não só se recusou a apoiar financeiramente o encontro internacional nórdico Jornadas pedagógicas do ensino do português, planeado para acontecer em Oslo em 2019, como também não permitiu essas jornadas no campus universitário.

\section{A FASE FINAL}

\subsection{Como pôde isto acontecer?}

Faltava pouco para continuar (e desenvolver) o português como estudo. Afinal de contas, bastava sobretudo contratar uma pessoa. Pergunta-se como o desmantelamento pôde acontecer. Quais as razões não exprimidas? Um fator delicado, mas plausível, poderia ser falta de conhecimentos da liderança do Institituto e da Faculdade: Desde a ideia de que o espanhol é a língua de Portugal ou do Brasil até uma analogia falsa com as línguas escandinavas a respeito de ensino comum de espanhol e de português. Outra possibilidade seriam ideias pedagógicas pouco convencionais: Que o ensino de literatura tem um significado secundário no estudo duma língua estrangeira a nível universitário, ou que as disciplinas linguísticas devem ser convertidas em estudos de área, reduzindo as línguas a um papel secundário e eliminando a literatura? Este último, aliás, é a tendência do desenvolvimento da Faculdade de Letras durante os últimos 30 anos: Deixou de haver disciplinas complexas de cultura na tradição filológica ensinadas por filólogos, para privilegiar disciplinas mais específicas (por exemplo literatura e linguística), fomentando uma "cientificação", até à situação atual, em que a faculdade é constituída por grandes institutos abrangendo uma variedade de disciplinas diferentes, verdadeiros conglomerados, institutos que não foram criados com uma base académica, mas sim para facilitar um certo tipo de gestão.

O ILOS representa um exemplo desta última fase, e a heterogeneidade tem como consequência prática a tendência de forçar as disciplinas "de base" a seguirem um padrão semelhante em todo o Instituto, por exemplo o modelo dos estudos de área. Quer dizer, para que o conteúdo duma disciplina seja determinado pela instituição - o que nunca poderia ter acontecido nos institutos constituídos por disciplinas genericamente ligadas, como no antigo Instituto das Línguas Românicas.

O português não é a primeira disciplina linguística a ser ameaçada na Faculdade de Letras. Contudo, comparado com o que foi feito há poucos anos para salvar o italiano, é fácil pensar que há línguas mais populares do que outras, e que a liderança do ILOS tem outros motivos que não a importância para a universidade e para a sociedade norueguesa, seja o prestígio da língua em questão ou próprios interesses, dado que o que uma disciplina perde é para o bem de outras. Ou será que o projeto desde o início era eliminar o português para distribuir os escassos recursos entre outras disciplinas já maiores?

\subsection{Condicionalismos estruturais}

Talvez a razão mais importante do desenvolvimento infeliz tenha a ver com o próprio modelo de gestão da Universidade de Oslo. Quando a professora de português, por fim, pediu uma audiência ao reitor da universidade, Svein Stølen, ele recusou-se, dizendo que todo o processo tinha decorrido como deve ser - seguindo os princípios do quadro de governação da universidade. Na prática um repúdio total de responsabilidade, porém correcto do ponto de vista formal.

Com a reforma administrativa de 2005, a gestão da Universidade de Oslo passou a ser baseada nos princípios do New Public Management (NPM), uma doutrina económica que assenta no princípio de que a gestão de instituições

26. Carta ao autor, datada 12 de abril de 2018 
públicas deve ser igual à que se pensa ser a das empresas privadas. Uma noção chave do NPM é "produção". Outra caraterística importante é a descentralização do poder de decisão. Uma pré-condição é a divisão da instituição em "unidades de resultado" mais pequenas, que recebem meios "livres" por meio do sistema financeiro, e não como antes na forma de fundos dedicados ou como reembolsos. Um terceiro elemento do NPM é a mediação: as unidades de resultados são geridas por meio de indicadores de objetivo. Por fim, o controlo (interno e externo) é importante.

$\mathrm{Na}$ Universidade de Oslo, fizeram das faculdades e dos institutos unidades de resultado, cujos chefes e subchefes - agora em posições $100 \%$ administrativas - tiveram amplas liberdades para definir como organizar e gerir os respetivos setores, incluindo por exemplo o direito de decidir os casos que têm a ver com a oferta de ensino e os planos de recrutamento - a expensas dos antigos órgãos democráticos. A produção de créditos, a dimensão de conclusão dos estudos, etc. foram escolhidas como indicadores de objetivo. Quanto ao controlo, o interno é concentrado no seguimento de leis e regras e na boa contabilidade, enquanto NOKUT e representantes externos nos conselhos diretivos dos institutos e das faculdades ficaram encarregado da fiscalização externa.

O motivo para tudo isto era a eficiência, mas também dar às unidades a vários níveis um espaço de manobra para gerir os recursos, baseado no que é preciso localmente, como uma espécie de operacionalização da autonomia académica. Contudo, para o modelo funcionar na prática, duas condições básicas devem ser cumpridas: o reconhecimento dos chefes a todos os níveis da missão académica e social da universidade, e não só o seguimento do modelo administrativo como se fosse um objetivo em si. Por outro lado, é preciso uma certa homogeneidade das unidades para impedir decisões dos chefes sem fundamento estritamente académico. Na Universidade de Oslo, essas condições não foram preenchidas. Da mesma forma, os indicadores utilizados para medir a "produção" das unidades de resultado também não servem para fiscalizar se uma universidade faz jus ao seu desígnio, sendo o objetivo duma universidade oferecer educação superior, realizar pesquisa e desenvolvimento além de divulgar conhecimentos, ${ }^{27}$ baseado num plano académico. Os indicadores não têm validade. Finalmente, medir a dimensão de conclusão dos estudos é problemático. Com efeito, existe muito espaço para arbitrariedade no que tem a ver com os indicadores (SANTOS, 2018). Também a fiabilidade é baixa.

Este modelo de gestão foi determinante no caso do desmantelamento do português: A liderança administrativa do ILOS teve o poder de suprimir um dos recursos essenciais do curso, a cátedra de literatura, a fim de conferir meios a um outro curso substancialmente diferente sem razão académica manifesta nem qualquer motivação social. Os valores assumidamente baixos dos indicadores de objetivos foram utilizados como argumento para encerrar o curso de bacharelato em português. Em suma, chefes administrativos, chefes da primeira linha numa instituição pública, tiveram o poder de não só passar por cima de razões académicas, mas de tomar medidas contrárias à política oficial do governo - poder esse que foi aceite pelo reitor da universidade e também pelo Ministério da Educação e de Pesquisa. Assim, o caso do português mostra que a autonomia académica se tornou uma autonomia só para os chefes.

\subsection{A universidade de então e a de agora}

Não só o modelo de gestão, mas também as atitudes dos chefes da Universidade de Oslo atual divergem claramente da ideologia dos antigos. No fim dos anos 1960, a liderança mostrava uma atitude ofensiva quanto à expansão profissional que achava necessária. Tomava iniciativas próprias para desenvolver o português como disciplina, tanto na elaboração dos orçamentos, como nas tentativas de arranjar financiamento externo. A carta ao Instituto de Alta Cultura para pedir um professor português é um bom exemplo. ${ }^{28}$

Em 2016, a chefe do Instituto sustentou num artigo no Uniforum que "o ILOS assume a responsabilidade do português (---)". Agora vemos o que isso significa. Quando se procura nas páginas da Internet (6 de março 2019) sobre o acesso ao ensino superior a nível nacional, Samordna opptak, para saber onde se pode estudar português na Noruega, a resposta é "Não se encontram estudos nenhuns." Em comparação: Quem procura 'espanhol' no mesmo lugar, fica a saber que existem cadeiras de um ano, bacharelato e mestrado em quatro universidades e duas escolas politécnicas na Noruega, além da Norges handelshøyskole. Os estudos latino-americanos já não existem na Universidade de Oslo. O contraste com os pensamentos de Leif Sletsjøe por volta de 1950 sobre os estudos iberoamericanos é flagrante.

27. \$1-1 da Lov om universiteter og bøyskoler, a lei norueguesa sobre as universidades e institutos politécnicos.

28. Veja-se secção 2.2. Também a iniciativa em 1988 de fomentar estudos da literatura brasileira, mencionada na secção 3.1 . 
Visto de fora, podemos resumir a situação, dizendo que, no início, a Universidade de Oslo abriu-se ao mundo inteiro e mostrou interesse em abranger tudo o que era relevante para a sociedade norueguesa, enquanto que agora a universidade está a fechar-se a uma grande parte dele - ao contrário de todo o falatório sobre internacionalização em prejuízo da universidade, da ciência e da sociedade.

Isto em relação à prática. Mas o que é que caracteriza a ideologia subjacente à universidade que estava em (re)construção há 50 anos?

\subsection{A ideologia}

A ideologia nunca foi explicitada. Mesmo assim, a impressão com que se ficava como estudante, funcionário, pesquisador ou professor, era o ideal duma universidade cujas partes deviam cobrir uma área científica tão extensa quanto possível a todos os níveis e academicamente defensável, e que entre estas partes existia uma relação recíproca de dependência ou pelo menos de utilidade. O desmantelamento do português como disciplina é um de vários sinais de que a Universidade de Oslo se tem afastado desta conceção de universidade.

Idealmente, uma universidade seria um todo "orgânico", racional, que toma em conta exigências de fora e de dentro, mas que tem uma democracia interna, como descrito em 2009 na proposta para uma estratégia da Universidade de Oslo nos anos 2010-2020. ${ }^{29}$

Mas, de facto, a universidade tornou-se uma instituição com uma liderança independente e descentralizada, sem democracia interna, que fomenta uma carteira fragmentária de disciplinas, aposta em projetos temáticos de pesquisa, e assenta na ideia do "mercado" das disciplinas, com base apenas na procura dos estudantes, de forma a maximizar o número de créditos possível.

Todos estas características são claramemte prejudiciais para cursos pequenos: as disciplinas escolhidas são sempre as grandes, que ficam ainda maiores em detrimento das pequenas, para satisfazer as condições formais de NOKUT, e os projetos temáticos só podem ser levados a cabo pelas áreas com um corpo docente numeroso.

Além disso, a responsabilidade perante a sociedade na prática desapareceu, ou melhor, ficou reduzida a uma questão de indicadores e de satisfação de exigências formais pouco confiáveis.

Se recordarmos os argumentos de Leif Sletsjøe quando preparou o terreno para o estabelecimento do português como disciplina universitária, fica claro que não se harmonizam com as manobras contabilísticas que parecem ser o fundamento da universidade atual. Apontava para a rentabilidade para a sociedade, para a cultura e para a linguística

- "aspetos e usos diversos das línguas". Homem com uma certa experiência da vida prática, mas ao mesmo tempo ligado aos valores humanísticos, via como estas dimensões do conhecimento podiam e deviam ser combinadas na aprendizagem duma língua estrangeira.

Mas o que aconteceu com o outro factor de ativação do estabelecimento do português na Universidade de Oslo?

\subsection{A falta de interesse do setor empresarial}

O português não teria sido estabelecido como curso universitária no fim dos anos 1960 se não fosse o empurrão da companhia Øivind Lorentzen A/S. Contudo, a posição do setor empresarial em relação à Universidade de Oslo mudou. Em princípio, o setor, representado pela Organização Empresarial Nacional (Næringslivets Hovedorganisasjon, NHO), é em favor do ensino do português na Noruega, e o português aparece no "barómetro de competências" de que as empresas norueguesas precisam. ${ }^{30}$ Não obstante, e ao contrário de várias das empresas sócias, a NHO não está disposta a apoiar o português como disciplina universitária na prática. Talvez por medo de interferir na célebre autonomia académica da universidade, ou simplesmente por ter uma ideia simplista sobre a aprendizagem duma língua estrangeira.

29. Høringsdokument for UiOs strategi 2010-2020, de 20 novembro de 2009

30.https://www.nho.no/siteassets/nhos-filer-og-bilder/filer-og-dokumenter/kompetanse-og-utdanning/nhos-kompetansebarometer- -nifu.pdf. Acesso em 1 de janeiro 2019. 


\section{LÍNGUAS ESTRANGEIRAS E UMA ÚLTIMA ESPERANÇA?}

As páginas da Faculdade de Letras da Universidade de Oslo na Internet estão cheias de bons pontos de vista e de boas intenções - em contraste com a prática da faculdade. Por exemplo, na página na Internet do programa de estudos em línguas europeias (bacharelato) pode ler-se: "Conhecimento de línguas, culturas e sociedades é crítico para percebermos e explicarmos o que acontece na atualidade." ${ }^{\prime 31}$

Neste contexto, há toda a razão para lembrar que línguas nesta citação quer dizer 'língua estrangeira' e que este último não é característica duma língua individual, mas, sim, uma relação entre uma língua e a língua materna: O português é uma língua estrangeira na Noruega em relação à língua norueguesa. Além do mais é preciso fazer questão em que o ensino de uma língua estrangeira em relação ao norueguês deva acontecer na Noruega - pelo menos na primeira fase dos estudos - como consequência prática do facto de que o norueguês só se fala na Noruega. A Noruega é o único sítio onde há a competência suficiente e adequada desta língua. Eis a necessidade de manter um centro de competência do português como língua estrangeira na Noruega. Para não ficar limitado a cursos rápidos e informação superficial é preciso que este centro tenha a qualidade duma instituição de ensino baseado na pesquisa, como deve ser num ambiente académico. Para uso "imediato", e a longo prazo. Para esta competência ficar acessível quando for precisa. Para a Noruega, é uma responsabilidade nacional. Com efeito, é essencial manter uma verdadeira competência de línguas estrangeiras estratégicas como parte da infraestrutura imaterial da sociedade. Para citar a contribuição do mesmo ILOS ao plano estratégico da universidade para os anos 2010 - 2020: "É decisivo para a capacidade da universidade se readaptar estar preparada para uma realidade global rapidamente variável." Nesta perspetiva é interessantíssimo ver a implementação do governo das próprias intenções exprimidas no livro branco já mencionado (na secção 8.2).

Em 2018, o governo anunciou a nomeação de um grupo de peritos cuja tarefa era examinar a situação das pequenas disciplinas ameaçadas nas faculdades de letras. "O grupo avaliou a necessidade de estabelecer um regime de financiamento para assegurar as necessidades nacionais. ${ }^{132} \mathrm{O}$ único membro do grupo que era linguista era uma professora catedrática de francês. O chefe do grupo era um professor de história económica da Universidade de Oslo - pró-decano de pesquisa 2011-14, quando o corpo docente do português foi reduzido a 50\% com o cancelamento da cátedra de literatura. O grupo publicou a sua recomendação em 13 de setembro de 2019. Basicamente, o que eles recomendam é abrir a possibilidade de financiamento só se for necessário, e não um financiamento regular. Quer dizer que a recomendação é baseada na situação atual - para salvaguardar a carteira de disciplinas universitárias atuais. O que implica que fica sem efeito no caso do português.

\section{CONCLUSÃO}

O que aconteceu com o português pode acontecer com qualquer outra língua estrangeira em qualquer país, mas aconteceu na Noruega. É um caso que destaca a condição frágil duma língua estrangeira em geral, ilustrando como as realidades práticas podem, com o tempo, divergir das ideias e das boas intenções que levaram ao estabelecimento do curso. Mas aponta para uma falha específica no sistema de educação superior da Noruega. Em primeiro lugar, o desmantelamento do português na Universidade de Oslo significa uma destruição do canal de compreensão entre a Noruega e o mundo lusófono - num contraste gritante com as intenções proclamadas de estabelecer uma cooperação mais apertada, o que pode ser interpretado como uma falta de verdadeiro interesse de cooperação. Além disso, tem um aspecto político significativo que ultrapassa em muito o nível universitário - a nível nacional e até internacional, já que a relação da Noruega com os países lusófonos e, em particular, com o Brasil, fica lesada.

\section{REFERÊNCIAS}

ENGH, J. Portugisisk - verdensspråk og nasjonalt ansvar - 50 år med portugisisk som fag ved Universitetet $i$ Oslo. Oslo:Sypress, 2021.

FERREIRA DE CASTRO, J.M. Gummitapperne ved Rio Madeira. [A Selva]. [traduzido por Leif Sletsjøe] Oslo:Tiden, 1953.

31. https://www.uio.no/studier/program/euram/index.html

32. "https://www.regjeringen.no/no/aktuelt/vil-utrede-tiltak-for-sma-og-utsatte-humaniorafag/id2617010/. Acesso em 26 de outubro $2018 . "$ 
GOLDSTEIN, N. S. Depoimento. Uma experiência na Escandinavia. Em: Filologia e Lingüística Portuguesa, v. 2, pp. 273-279, 1998.

GRØNSTAD, A. Eit globalt perspektiv på humaniora. Em: På bøyden. Bergen 2015. Disponível em: < http://pahoyden.no/ debatt/2015/01/eit-globalt-perspektiv-pa-humaniora >. Acesso em 1 de janeiro 2019.

HOLM, P.; JARRICK, A. e SCOTT, D. Humanities World Report 2015. Basingstoke:Palgrave Macmillan UK, 2015.

LONDRIM, G. de S. C.; SANTOS, D.; MICHAELSEN, F. V.; JANSEN, H.. Viva!:portugisisk fremmedspråk - nivå 1. Bergen:Fagbokforlaget, 2017.

MUHR, R. (ed.) Pluricentric Languages and Non-Dominant Varieties Worldwide II: The Pluricentricity of Portuguese and Spanish. New Concepts and Descriptions. (Österreichisches Deutsch - Sprache der Gegenwart) Frankfurt am Main:Peter Lang, 2015.

NILSSON, K. Norsk-portugisisk ordbok. (Scandinavian university books) Oslo:Universitetsforlaget, 1979. [2a edição 1994]

NILSSON, K. A lusofonia vista por um Lusitanista Escandinavo. Caderno do Centro de Línguas 2. Ensino de Português língua Estrangeira. USP. São Paulo:Humanitas pp. 49-73, 1998.

SANTOS, D. Portugisisk i verden. (Fokus på språk) Halden:Fremmedspråksenteret, 2015. Disponível em: <https://www.hiof.no/fss/ leringsressurser/uh-sektoren/forskning-og-utvikling/fokus-pa-sprak/fullstendig-publikasjonsliste/portugisisk_i_verden_ korrigert_web.pdf $>$. Acesso em 1 de janeiro 2019.

SANTOS, D. Português internacional: alguns argumentos. Em TEIXEIRA, J. (ed.). O Português como Língua num Mundo Global: problemas e potencialidades. Centro de Estudos Lusíadas da Universidade do Minho, 2016, pp. 49-66. Disponível em: https://www.linguateca.pt/Diana/download/Santos2016PI.pdf>. Acesso em 1 de janeiro 2019.

SANTOS, D. Portugisisk, tall og politikk. Uniforum 22 de janeiro de 2018. Disponível em: <https://www.uniforum.uio.no/ leserbrev/2018/portugisisk-tall-og-politikk.html>. Acesso em 1 de janeiro 2019.

SLETSJØE, L. Latin-Amerika og vi. Verdens gang 5 de outubro de 1949.

SLETSJØE, L. Trenger vi et Ibero-amerikansk institutt. Aftenposten 17 de agosto de 1953.

TØNNESSEN, E. Vil videreutvikle satsing mot Brasil. Kbrono 28 de novembro 2015. Disponível em: <https://khrono.no/ internasjonalt-samarbeid-brasil-kronprins-haakon/vil-videreutvikle-satsing-mot-brasil/163347>. Acesso em 1 de janeiro 2019. 


\section{ADENDA}

\section{A organização dos estudos e dos exames na Universidade de Oslo}

A Universidade de Oslo é organizada em faculdades, uma destas sendo a Faculdade de Letras que, por sua vez, é dividida em institutos. Os institutos têm um chefe contratado por um número de anos limitado, e têm um conselho diretivo, "styre", com representantes eleitos do corpo docente, dos docentes temporários incluindo os estudantes de doutoramento, dos funcionários da administração e dos estudantes. O chefe do instituto tem um amplo poder para decidir assuntos sem consultar o conselho diretivo.

Um dos institutos é o ILOS. Em 2020, o ILOS oferece 4 programas de estudos, "studieprogram", dois ao nível do bacharelato/"bachelor": 'estudos estéticos e literatura', 'línguas europeias', e dois ao nível do mestrado/"master": 'literatura' e 'línguas europeias', além de cursos de um ano, "årsenheter".

No programa das línguas europeias, pode-se escolher entre 7 cursos. Cada curso é constituído por várias cadeiras, "emner". Dado que o português já não é um curso, só pode ser estudado como ramo auxiliar doutro estudo, por exemplo o espanhol.

A duração normalizada do bacharelato é de 3 anos, e a do mestrado de 2.

Antes da reforma de 2003, os institutos ofereciam cursos de um semestre, "semesteremne", de um ano, "grunnfag", de 1,5-2 anos, "mellomfag", e de "hovedfag", mais 2-3 anos. O último correspondia formalmente ao mestrado atual. $\mathrm{Na}$ altura que o curso de português foi implementado, a combinação de um "grunnfag" e dois "mellomfag" (que tinham de ser em disciplinas académicas diferentes) tinha a denominação "cand.mag.", normalizado a aproximadamente 5 anos. (Durante alguns anos antes da reforma de 2003, outras combinações também foram possíveis.) Um "hovedfag" (que tinha de ser continuação de um dos "mellomfag") dava direito ao título "cand. philol", o que correspondia a aproximadamente 7 anos no total. Para além do mais, existia antes de 2003 um grau entre "cand.philol. " e doutoramento, "magistergrad", exame tradicional da faculdade dedicado aos estudantes com interesse de se dedicar à pesquisa. 